\title{
2 Gender and home in Japan and Norway: Considering the past and contemplating the future
}

\author{
Kristensen Guro Korsnes, \\ Ringrose Priscilla, and Ishii-Kuntz Masako
}

\section{What is a home and what does gender have to do with it?}

The aim of this chapter is to discuss and compare the ways in which gender and home are intertwined in Japan and Norway, exploring both their historic and contemporary contexts. Our overarching focus is the gendered meanings that have been and are presently ascribed to the home in Japan and Norway. We use our discussions of this meaning-making to reflect on what we can learn from national particularities and similarities across the two contexts in the light of today's globalised world, and to contemplate potential trends relating to the gendering of the private sphere.

In sociological and cultural research, the notion of home is often ascribed a straightforward empirical meaning. It is defined as a place of shelter, a space where people live, sleep, eat and provide or receive care. Importantly, the home enables people to withdraw from the outside world into a private sphere. In line with this, Carsten (2004) describes the home as a central place for the creation of family ties, given that relations of kinship often emerge 'through the intimate sharing of space, food, and nurturance' (p. 35). In most societies, the home is conflated with family, whether structured as a nuclear family or as an extended family combining several generations and/or many relatives (Carsten, 2004, p. 35). Moreover, the notion of the home often evokes a sense of attachment and belonging, in the sense that the expressions 'being at home' and 'feeling at home' connote being at peace and feeling comfortable (Moore, 1984). The home has also been described as a haven from the pressures of the outside world, as well as a site for leisure and recreation (Carsten, 2004).

At the same time, these rather idealised understandings of the home have been contested by other strands of research. These often examine the home as a potentially unsafe space for children, women, the elderly and others who are at particular risk of domestic violence. Similarly, scholars find that home may not signify stability or safety for migrants. In line with this, migration research points to the many millions of migrants who for various reasons have left their homes behind in exchange for more or less temporary residences in a new region, country or continent (Chatterjee, 
forthcoming 2022). Finally, another significant way of understanding the modern notion of home is to see it as a gendered realm, a private 'feminised' space strongly associated with the world of women. This stands in contrast to the 'masculinised' public sphere, more closely aligned to the domain of men (Erel, 2011; Lister, 2003; Pateman, 1989; Solheim, 1998).

Taking our inspiration from these general accounts of 'the home,' we 'home in' on the Norwegian and the Japanese contexts to ask: What gendered meanings are ascribed to the home in the two national contexts, both historically and today? What similarities and differences can we see? What are the most significant issues which emerge when gender is at stake?

\section{Research methods}

To explore these questions, we surveyed a wide range of social science and cultural studies research publications from Norway and Japan which engage with the concepts of home and gender in either Norway or Japan. These texts include both quantitative and qualitative studies and cover both historical and contemporary perspectives. Whereas the quantitative studies provide information about the statistical patterns relating to the Norwegian and Japanese home and domestic life, the qualitative studies provide insights into the cultural meanings that are attached to the Norwegian and Japanese home and to everyday life within the home historically and today.

We conducted online searches by using the search words 'home and gender' and 'gendered notions of the home' combined with 'Norway' or 'Japan' in standard academic search engines and databases. As homeowners living in and feeling a sense of belonging to Norwegian or Japanese homes ourselves, we also draw on our personal experiences and observations as insiders, whereas our position as outsiders to the other national context has helped us identify tacit knowledge which would otherwise not have found its way into the text.

As Irene Cieraad notes in At Home: An Anthropology of Domestic Space (1999), even though it is generally taken for granted that cultural conceptions of the home have some kind of national particularities, there are relatively few comparative studies in this field. In this chapter, we use comparison as an analytical tool to draw our attention towards similarities and variance. The overarching aim of the comparative perspective as we approach it is to reveal unique aspects of each national context that would be hard to detect otherwise (Mills et al., 2006).

\section{The Norwegian home}

Scholarship on the 'Western home' views it as a distinct entity, a social construct which has undergone dramatic changes as a result of the processes of 
modernity and the rise of capitalism. These forces have transformed the home from a site centred around the family as a self-sufficient production unit to a place where women are fulfilling their supposed 'natural mission' to clean, care and cook, and where men working outside the home can retreat (Lasch, 1977). This change created a new, highly gendered division between the private (home) as associated with women and the public (work) with men. Following this, a discourse emerged glorifying women's role in homemaking, and celebrating the home as her 'haven' (Solheim, 2007; Somerville, 1997).

\section{Home ownerships and trends}

The home is not only the cornerstone of the Norwegian way of life; it is a personal and highly adorned castle, where time and money are invested, and where life unfolds. (Brusdal, 2006, p. 35)

This statement about the Norwegian home echoes the perspectives of other researchers in both the Humanities and the Social Sciences, who present the home as a very important part of Norwegian life - on both practical and ideological levels (Gullestad, 1992; Solheim, 1998). Compared to many other national contexts, including European ones, home ownership is very common in Norway. Currently eight out of ten Norwegians are homeowners, and $98 \%$ can expect to own a home at some time in their lives. ${ }^{1}$ This trend has its roots in post-war national policies which explicitly aimed at creating a nation of homeowners.

The post-war home envisioned in Norwegian housing policies was popularly known as 'two rooms and a kitchen' - meaning a simple apartment with one living room, a bedroom, a bathroom and a kitchen for a couple and their two children to share. This meant that the whole family would often share one bedroom. In contemproary Norway houses and appartments are expensive (particularly in urban areas), and, as such, they usually represent a family's greatest investment and most important economic asset. Moreover, due to the steady rise in house prices over the last decades, housing has become an important market for investors. To buy a home in Norway, you must obtain mortgage approval from a bank before you can even start viewing houses or apartments. Property prices are determined as a result of a bidding process. This means that only those with inherited wealth, a very high income, or previous beneficial investments in the housing market can afford a detached home in an inner-city district.

High property values in urban Norway mean that many city dwellers to live in small homes, whereas rural residents typically enjoy much more spacious dwellings. In both urban and rural areas today, a large number of single occupant households exist. In 2020, 39\% of Norwegian households were single occupant households, and the average size of Norwegian households was 2,15 persons (Andersen, 2020). Whereas most Norwegians 
at some time in their adult life live with another person or their own children, multigenerational households are rare in Norway. In the case of student accommodation, however, the custom of cohabitating with peers is widespread. Even though Norwegians have relatively spacious homes, many also own a modest cottage ('hytte') in the mountains or holiday house by the coast. These cottages and holiday houses are used for weekend holiday breaks and function as second homes (Brusdal, 2006).

Another important aspect of the Norwegian home is the strong concurrence between the house and the family, and, more specifically in the 20th and 21st centuries, between the house and the nuclear family. According to the social anthropologist Marianne Gullestad, the most important function of the Norwegian home is to provide a setting for modern intimacy (Gullestad, 1993). As Gullestad formulates it, 'Norwegians do not only have houses, they have homes. The word hjem (home) brings together in one notion both the idea of a place and the idea of social togetherness associated with this place' (Gullestad, 1993, pp. 88-9). The home functions as the family's 'territory,' and the house is where its intimacy is played out (Gullestad, 1992). This conflation between family and home is also very much the case with the second homes (the cottage or the holiday house), as they are often handed over from one generation to the next, after years of overlapping use involving various cross-generational activities (Døving, 2020). Whereas children move out of the ordinary family home when they grow up, no one moves out of the cottage or holiday house. In this sense, the house, that is the first home, is more oriented towards the nuclear family, whereas the second home is more oriented towards the extended family (Døving, 2020).

At the same time, the Norwegian home is also a significant site for interaction with friends and sometimes even colleagues, both informally and for more organised parties and celebrations. Whereas pubs, parks, etc., are important meeting places in many other countries, in Norway the home is often the default setting for social activities beyond family ties. This means that the Norwegian home, especially the kitchen and living room, and everyday life in the home in these spaces is somewhat more public and also more on display than in many other countries. Following from this, the home is for many Norwegians a life project where identity is both constructed and communicated. According to Gullestad (1993), Norwegians 'use the home to create and express their specific ideas of identity and intimacy' (p. 89). Renovation and home decoration are important parts of this life project. Occupants' selection of colours, furniture and special consumer goods tell other people what kind of persons are living here (Brusdal, 2006). When it comes to interior aesthetics, a 'good' Norwegian home has traditionally been imagined as cosy, informal and warm (Brusdal, 2006; Gullestad, 1993, 2002; Lorentzen, 2008). In the past decades, this warm cosiness has in part been replaced by a more 'clean and functional' 'Scandinavian design,' as it is presented and sold in, for example, the Swedish furniture chain IKEA. 
The cosiness of the old times, as well as the more functional 'modern' style, have been and to a great extent still are the responsibility of women, who would typically be the ones hanging up the paintings on the wall and lighting the candles in the living room in the evenings, and it is women's identities which are most symbolically projected onto the interiors and style of the Norwegian home (Gullestad, 1984/2001). It is not surprising then that women consume far more home decoration magazines than men, in which they also figure much more predominantly as the lead consumer/ decorators. In line with this, women are more frequent consumers of furniture and other home decoration items than men. In times where gender equality is an ideal, men have, however, been increasingly entering the domestic arena. Still men tend to be more associated with the exterior housework, where they do more of the work, whereas women are still envisioned as the ones ruling inside (Kristensen, 2016). According to social anthropologist Runar Døving (2001), this association between women and the home has often been misinterpreted as some kind of oppression of women, yet quite a few women are enjoying their role in the home and find it to be a means of expression and creativity, using this position to exercise power in terms of making decisions regarding the family's social networks and daily routines. Examples of rather typical Norwegian homes are found in this photographs (Figures 2.1, 2.2, 2.3, 2.4, 2.5).

\section{The home in the housewife era and in times of gender equality}

Whereas Norwegian men have traditionally been responsible for the financial aspects of home ownership, as well as for maintenance work on the exteriors (and partly also interiors) of the home, as we have seen, women have traditionally been responsible for turning houses into homes. This was particularly true in the increasing affluence of the post-war era, when men, as the family's breadwinners, provided financially for the family while their wives spent their days taking care of their children and fulfilling their role as professional, though unpaid, housewives and home makers - cooking, cleaning and caring from morning till night (Danielsen et al., 2014). While the housewife era can be dated back to the 19th century with the establishment of the housewife schools, it is the 1950s which are most often described as the golden age of the housewife (Lorentzen, 2013).

Home décor, which in the 1950s and 1960s had become available and affordable for more families, was also an important part of this gendered work of turning houses into homes (Døving, 2001). The high standards women maintained in the home bore the vestigial influence of the Norwegian public housewife schools' training, which spread across Norway from the late 1800s to the mid-20th century (Avdem \& Melby, 1985; Hagemann \& Roll-Hansen, 2005). Their aim was to professionalise 


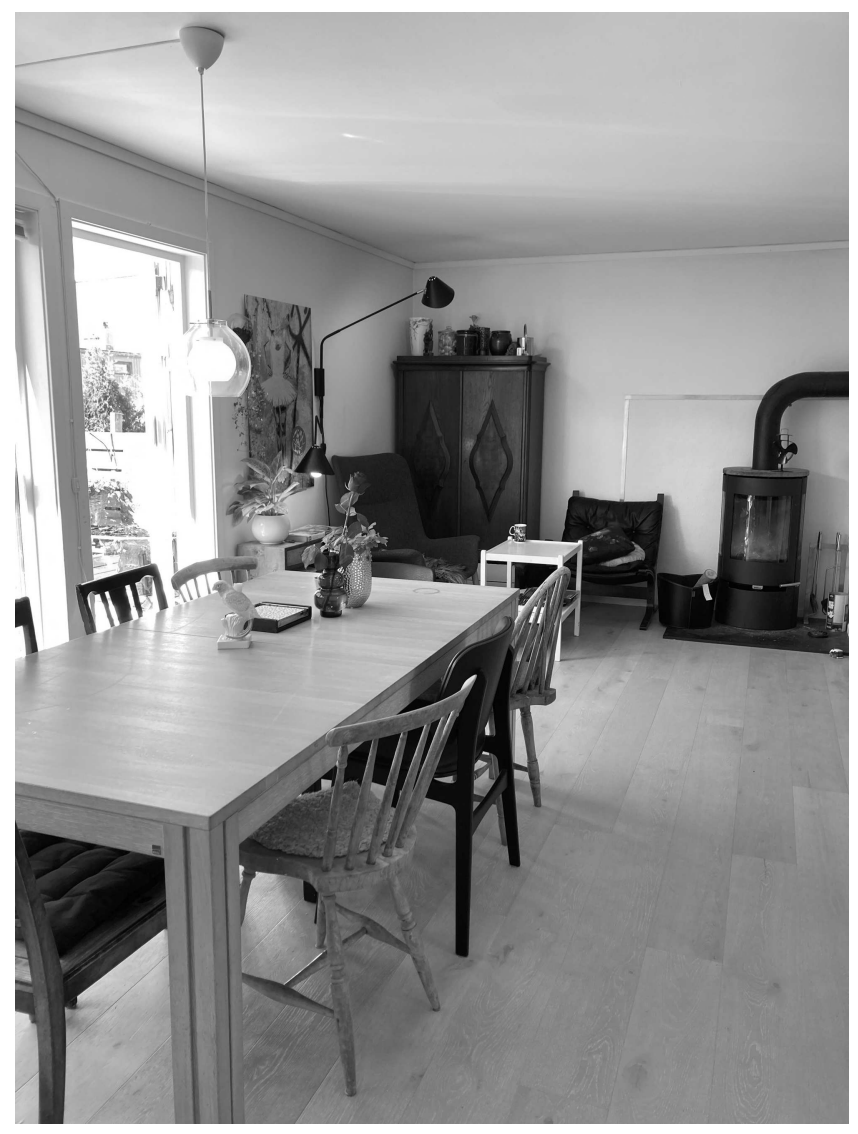

Figure 2.1 Norwegian living room; photograph by Guro Korsnes Kristensen.

'women's work' in the same way as the agricultural schools professionalised men's farm work (see Ch. 6 for more information). These schools created homemaking as a specialised arena which was reflected in the professionalised standards of housekeeping in private homes (Avdem \& Melby, 1985; Hagemann \& Roll-Hansen, 2005).

This traditional model was challenged in the 1970s by the feminist movement as Norway gradually transitioned to today's dual earner/dual carer model of gender equality, where both men and women work and care for their children (Danielsen et al., 2014; Ellingsæter \& Leira, 2006). As a result of women being more invested in paid work outside the home, the number of hours they currently spend on housework is low relative to previous decades, while on the other hand, men now take a more active role in housework and care work (Danielsen et al., 2014; Kitterød \& Lappegard, 2012). However, mothers of young children spend more time 


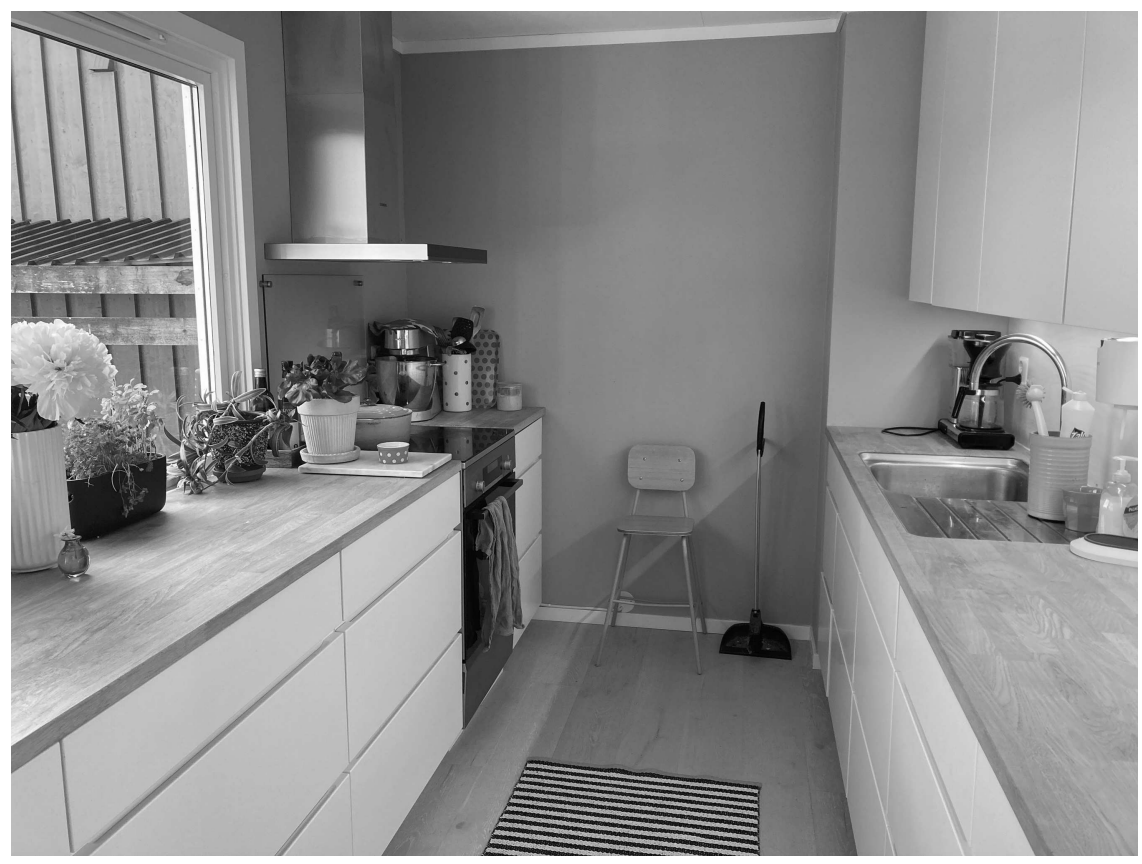

Figure 2.2 Norwegian kitchen; photograph by Guro Korsnes Kristensen.

on household work and less time on paid work than fathers of young children (Statistisk Sentralbyrå [SSB], 2018, p. 22). Having said this, gendered disparities during this stage of life have significantly reduced over the years, since fathers with young children spend more time on household work and less on paid work than previously, while the opposite is true for mothers. In 1980, the time that fathers spent on housework was $21 \%$ of that of the mothers, whereas in 2010, the proportion was 55\% (SSB, 2018, p. 23). For fathers, the time currently used on caring for the family amounts to $64 \%$ of the time spent by mothers, compared to $44 \%$ in 1980 (SSB, 2018 , p. 23). Whereas the post-war home was a site for women to 'do gender' in a traditional way, with clearly differentiated tasks and responsibilities for women and men, the dual earner/dual carer model for gender equality somehow transformed the home into a site for 'doing' gender equality.

\section{The modern Norwegian home - Gender equality as stress}

This new way of organising domestic tasks means that the actual doing of what Bridged Anderson (2000) once labelled the three Cs (cleaning, cooking and caring) in the home since the 1970s has become a way for 


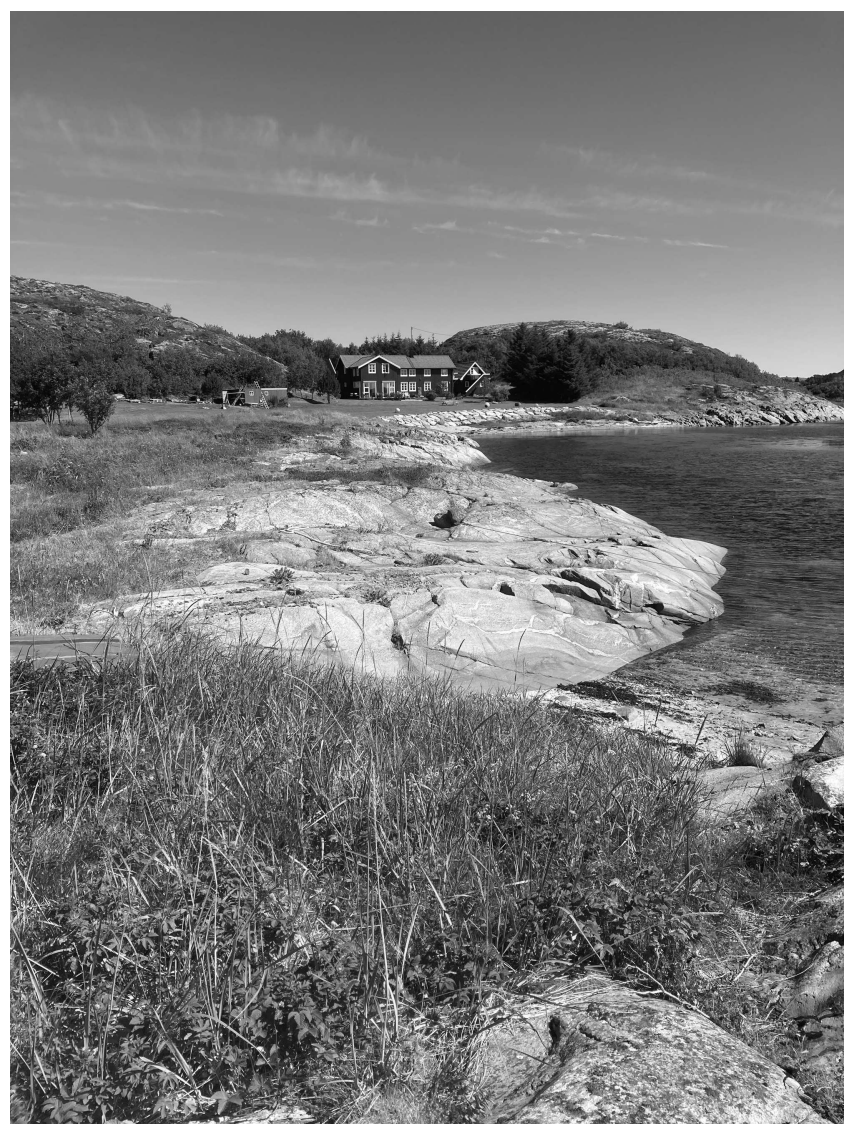

Figure 2.3 Traditional Norwegian house; photograph by Guro Korsnes Kristensen.

individuals and couples to become gender equal and to be seen as being gender equal. This means that the home is now considered the main domain where gender norms and gender equality ideals should be embraced, negotiated, and challenged (Døving, 2001; Klepp, 2006; Kristensen, 2017). According to sociologist Helene Aarseth (2011), Norwegian middle-class dual earner/dual carer couples who embrace the political and cultural ideal of gender equality turn all domestic tasks, including maintenance and construction work, into a self-realisation project where each member of the couple actively collaborates with the other in a 'gender-neutral' way. In line with this, Norwegian fathers' engagement in childcare is also seen as a typical expression of the Norwegian style of gender equality (Danielsen et al., 2014).

The other side of the coin is that the dual earner/dual carer model for gender equality has also turned the home into a site for arguments about 


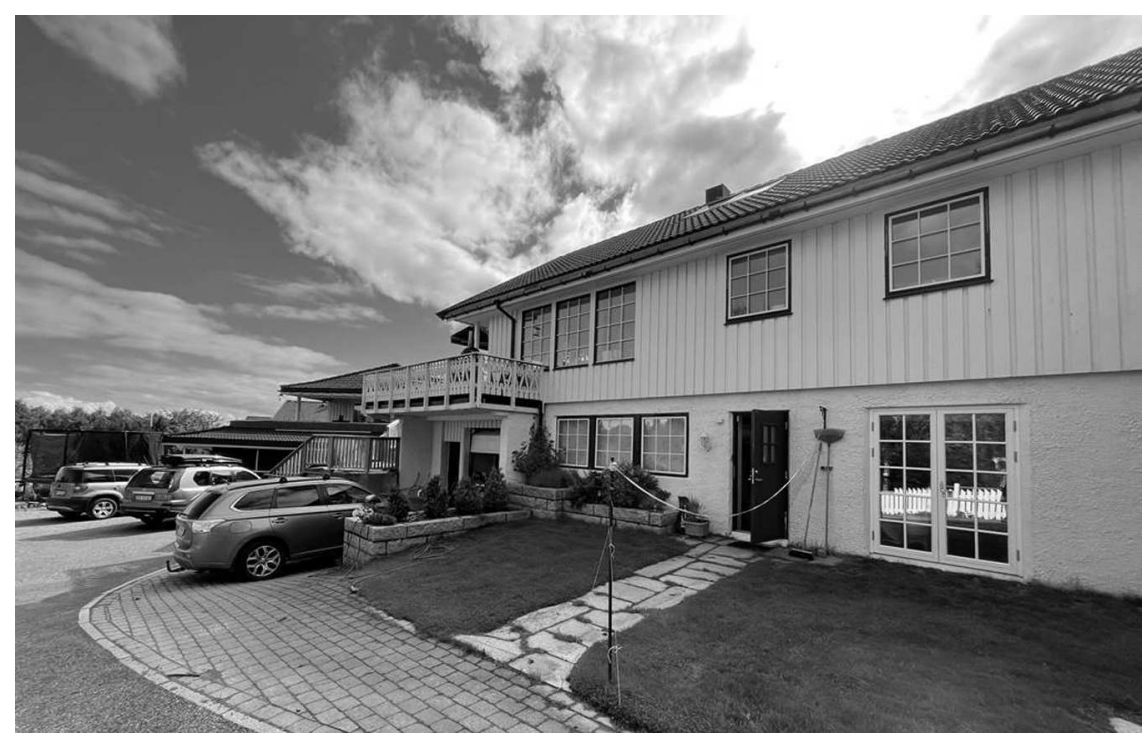

Figure 2.4 Norwegian house; photograph by Priscilla Ringrose.

domestic labour, and thus of the undoing of gender equality (Kristensen, 2016). Even though a lot of men have increased their efforts with cooking, cleaning and caring as more women have taken on paid work outside the home, this has not been enough to maintain the high standards of cleanliness carried over from the previous era's custom of female-dominated housework and home-making (Kristensen, 2016). Today, the combination of high cleaning standards and favourable economic circumstances mean that more and more Norwegians own an increasing number of 'things' and have an increasing amount of mess to be cleaned up in their increasingly spacious first homes, as well as in their second homes. And even though welfare state provisions for families have increased over this same period, this situation has been described as having led to a 'time-bind in relation to the home-work balance, in particular for families with young children (Kristensen, 2016; 2017).

For many Norwegian families, the time-bind - in part created by high standards for the cleanliness and style of their homes - is a pressing challenge which they attempt to solve in a variety of ways (Danielsen et al., 2014). One widespread solution which women opt for is to reduce their working hours (to continue) to take on the role of the primary homemaker (Kitterød \& Lappegård, 2012). Another solution to the time-bind is for couples to pay a third party to assist with domestic tasks. Compared to many other European countries, Norway does not have a history of hiring paid domestic labour. This was particularly true in the post-war era, when 


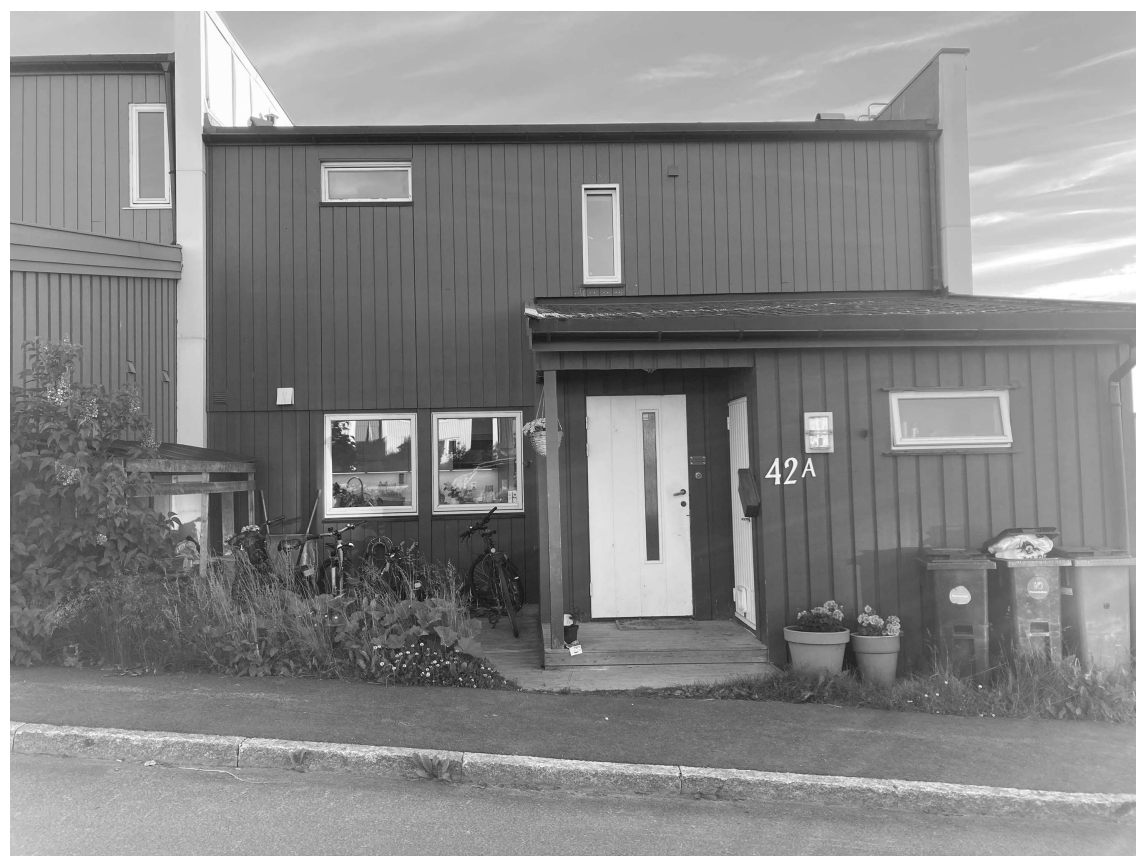

Figure 2.5 Norwegian house; photograph by Guro Korsnes Kristensen.

social democratic ideologies introduced a strong focus on public welfare and equality and when notions of social hierarchies and servitude were explicitly rejected (Sollund, 2010). In the last decades, however, this seems to have changed, as the employment of various kinds of domestic labourers has steadily grown in parallel to the growing pool of migrant labourers (Kristensen, 2016). The most common forms of paid domestic labour in contemporary Norway are in the areas of home cleaning and au pairing. Whereas the au pair arrangement, which in legal terms is regulated as cultural exchange and not work, is today most widely used by women from the Philippines (Utlendingsdirektoratet [UDI], 2020), the home cleaners are more often migrant women from Eastern Europe (Friberg \& Tyldum, 2007). Overall, au pairing is a much more marginal phenomenon in Norway than home cleaning, but it has nevertheless shown rapid growth in recent years (Kristensen, 2017).

These developments mean that more Norwegian families are outsourcing tasks that were traditionally labelled female but which today, in line with the dual earner/dual carer model of gender equality, are ideally expected to be shared between the couple. This also means that more and more families are employing an extra person who is not part of the family to help keep or take charge of keeping the house tidy and clean. Whereas this part-time 
employee helps keep the home clean and cosy even when the 'woman of the house' is out working, she also 'disturbs' the Norwegian home as the site of the nuclear family, and paradoxically she also represents a partial return to a time when the three Cs were not part of men's repertoire and when the home was a place for relaxation and not work.

\section{The Japanese home}

In the contemporary East Asian context, home usually means a place in which members coexist by providing essential physical and psychological care for each other. Historically, however, East Asian homes also functioned as a hierarchical unit based on age and gender. That is, elderly male members of the family controlled the household budget, and the eldest son and heir eventually assumed leadership from his father. In Japan, this patriarchal system, associated with the samurai class, is known as the ie system, which is also translated as 'household,' denoting both the physical home, the family members and the family lineage. Under this $i e$ system, the father was given absolute authority over individual family members in making all the important decisions, including the selection of an adult child's occupation and marriage partner. The Meiji Civil Code which went into effect in 1898) incorporated much of the ie system, retaining the power of the household head and making the family the basic unit of modern Japanese society; this Code remained in effect until the post-war reforms of the late 1940s.

Although such strictly patriarchal homes have largely disappeared in many contemporary East Asian countries, where partners have been ascribed equal status in the home, there still remains a strong emphasis on women's roles as mothers and homemakers and men's roles as breadwinners (Ishii-Kuntz, 1994; Smith \& Schooler, 1978) that can be traced to these traditional beliefs about the home. While the term 'good wife, wise mother' sounds outmoded, one still finds motherhood defined as women's primary mission in Japan.

In Japan, the home ownership rate was approximately $61.2 \%$ in 2018 , and has remained relatively unchanged since 2003 (Kettenhofen, 2021). Out of all the residential buildings in Japan, detached houses are the most popular, and the majority of ordinary Japanese households live in detached houses. The home ownership rate, however, varies considerably depending on the regions of residence. In larger metropolitan areas such as Tokyo, this rate is $45 \%$, whereas in rural Akita, a north western prefecture, home ownership is the highest for all of Japan at $77.3 \%$. Additionally, of the homeowners in the Tokyo area, $44.1 \%$ own condominiums rather than detached houses. The most popular floor plan of these urban condominiums is called 2LDK (2 rooms with a living+dining kitchen and a bedroom) and is similar to the small Norwegian urban family space. The smaller condominiums may reflect the fact that there are many more 


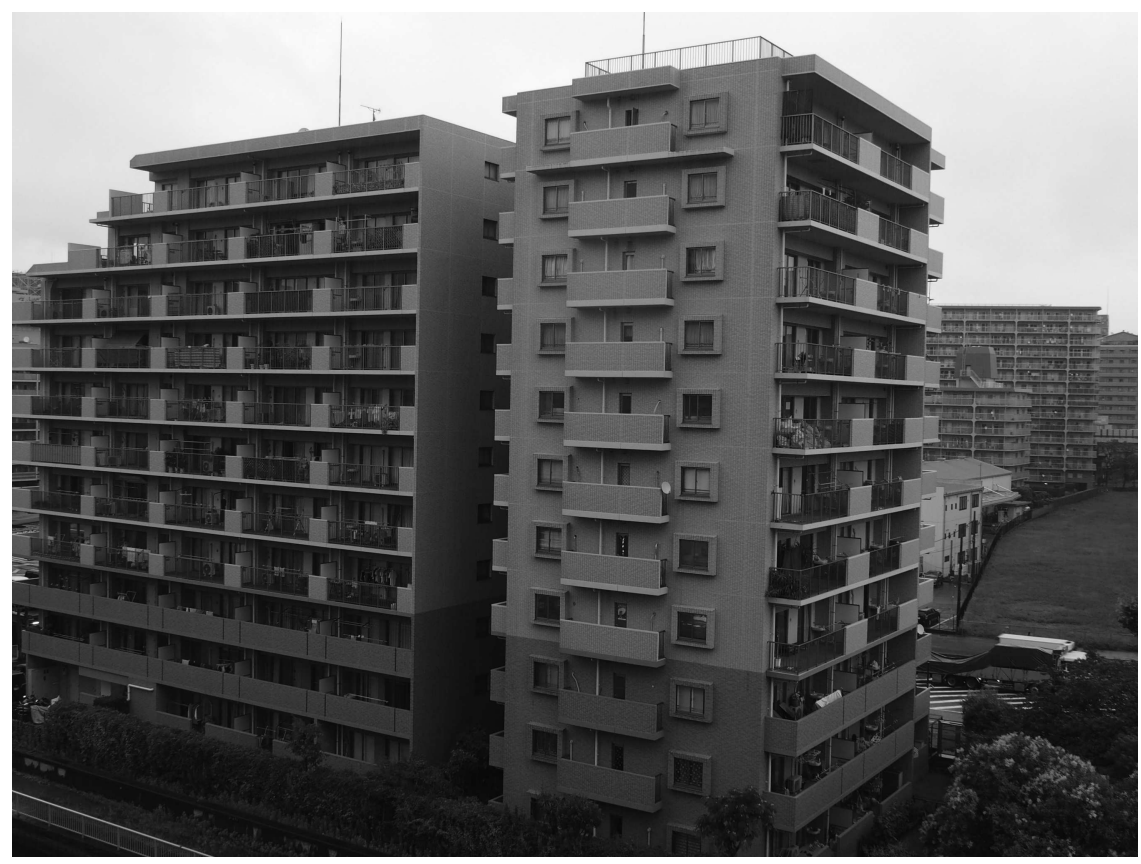

Figure 2.6 Japanese apartment buildings; photograph by Masako Ishii-Kuntz.

nuclear families living in larger cities and many more extended families living in smaller cities. Examples of typical Japanese homes in urban and rural areas are seen in the photographs (Figures 2.6, 2.7, 2.8, 2.9).

Home ownership has often been considered a dream for many Japanese as it symbolises the entry into true adulthood as well as long-term economic security. Also, as in Norway, home ownership represents a family's largest investment and most important financial asset. This trend seems particularly evident among Japanese men whose bread-winning responsibility is still considered their dominant role. Japanese homes, especially in less populated areas, are the places where family events such as birthdays and new year celebrations take place. This may not be the pattern in large cities because of the availability of many family restaurants and other gathering places as well as the relatively small sizes of homes. Other than these family events, large gatherings with relatives and friends are not common in Japanese homes. This can be explained by the clear division between public and private spheres in which home is considered the most private place to which even relatives and friends are not usually invited. As a result, Western type large gatherings which take place in private homes and gardens, such as barbeque parties, are very uncommon in Japan. Because of this public-private division, even co-workers and colleagues in Japanese workplaces may have no idea about each other's homes. 


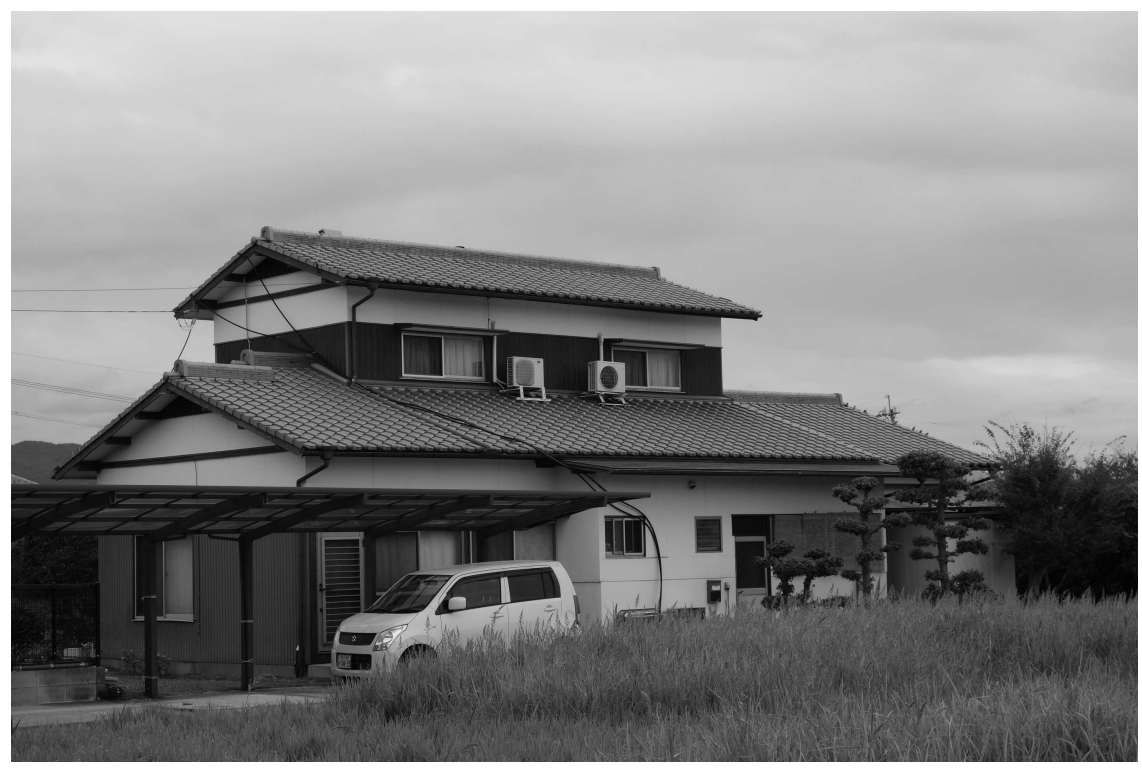

Figure 2.7 Japanese house; photograph by Juliette Ringrose.

In Japan, as in Norway, many magazines are devoted to homemaking and home décor that frame women as the main consumers/designers, and Japanese, too, struggle with an excess of things in their homes, a phenomenon that gave rise to the popularity of decluttering experts such as Marie Kondo.

Another recent trend regarding Japanese homes is the shut-in (bikikomori) phenomenon. This issue refers to the population of young men, who are frequently eldest sons, that have shut themselves off from the world by retreating in their bedrooms. Although a small percentage of young women have become shut-ins, too, the issue is mainly associated with men; many of these men continue to keep up this social withdrawal even as they reach middle-age and their (financially supporting) parents become elderly.

\section{The historical Japanese home as a gendered institution}

Of all the social institutions in Japanese society, home is perhaps where gender inequality is most constantly displayed. According to the report of the Gender Equality Bureau Cabinet Office (2016), approximately 44.7\% and $37 \%$ of Japanese men and women, respectively, think that it is better for men to be breadwinners and women to be homemakers. Men's participation in childcare and housework is quite limited, with an average of 


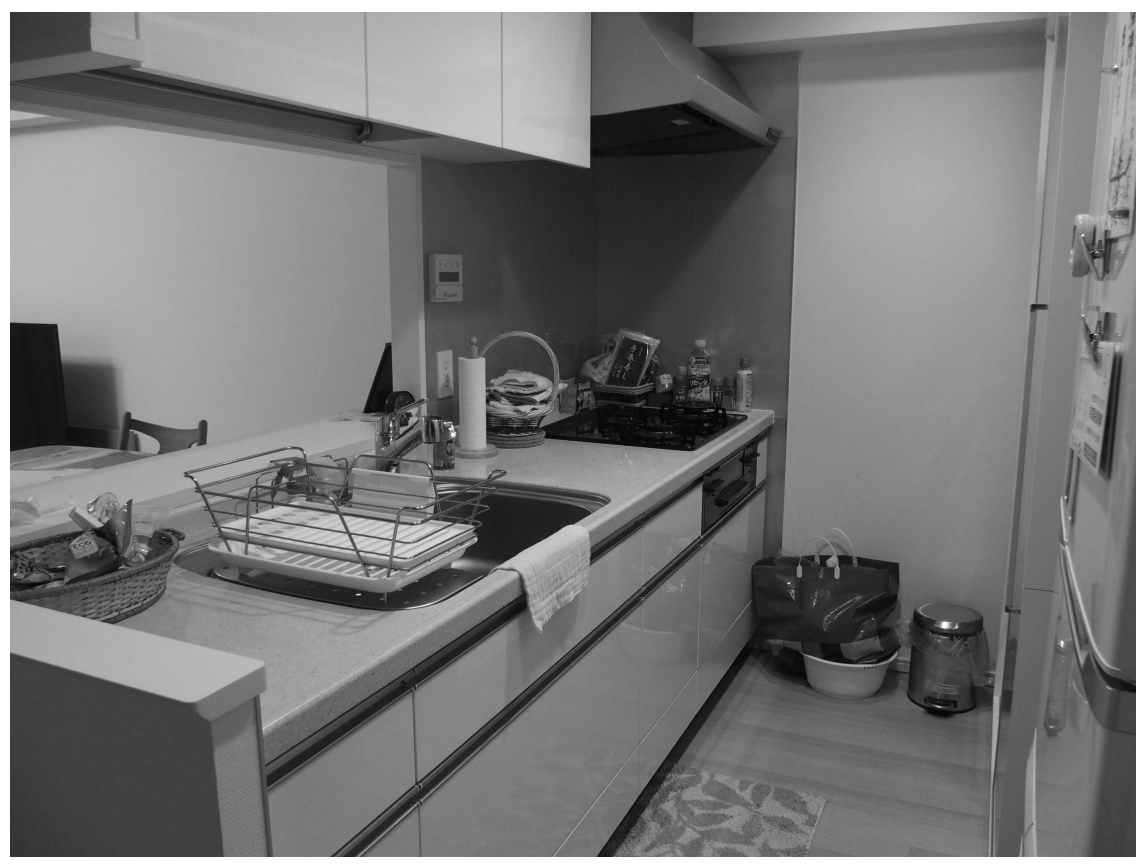

Figure 2.8 Japanese kitchen; photograph by Masako Ishii-Kuntz.

1.4 hours per day spent on these activities. This is considerably lower than the figure for women (7.6 hours). In addition, many Japanese believe in the so-called 'three-year-old myth,' which emphasises the critical role mothers play in their children's first three years of 'healthy' psychological development (e.g., Tama, 1985). Several studies in Japan also point out how traditional gender roles are learned at home with lasting impact on women's and men's educational and career choices (e.g., Sasahara, 2008). In the following, we will briefly present the historical antecedents of the modern-day gendered home.

The concept of 'home' first appeared in the 1880s during Japan's Meiji period, which marked the rise of women's homemaker roles (Muta, 1996). Within the aforementioned ie system, brides marrying into the family found themselves under the strict supervision of their mothers-in-law, felt pressure to produce male heirs and had few rights in divorce or to property. In common with other East Asian family models, the ie system upholds Confucian values of loyalty, which demand that family members show respect to the household head (Kitano, 1976). In the late 19th century, Japanese intellectuals coined the term 'good wife, wise mother,' blending Victorian notions of women's place in the Christian home with Confucian values of loyalty, to argue for women's education and their modern role in 


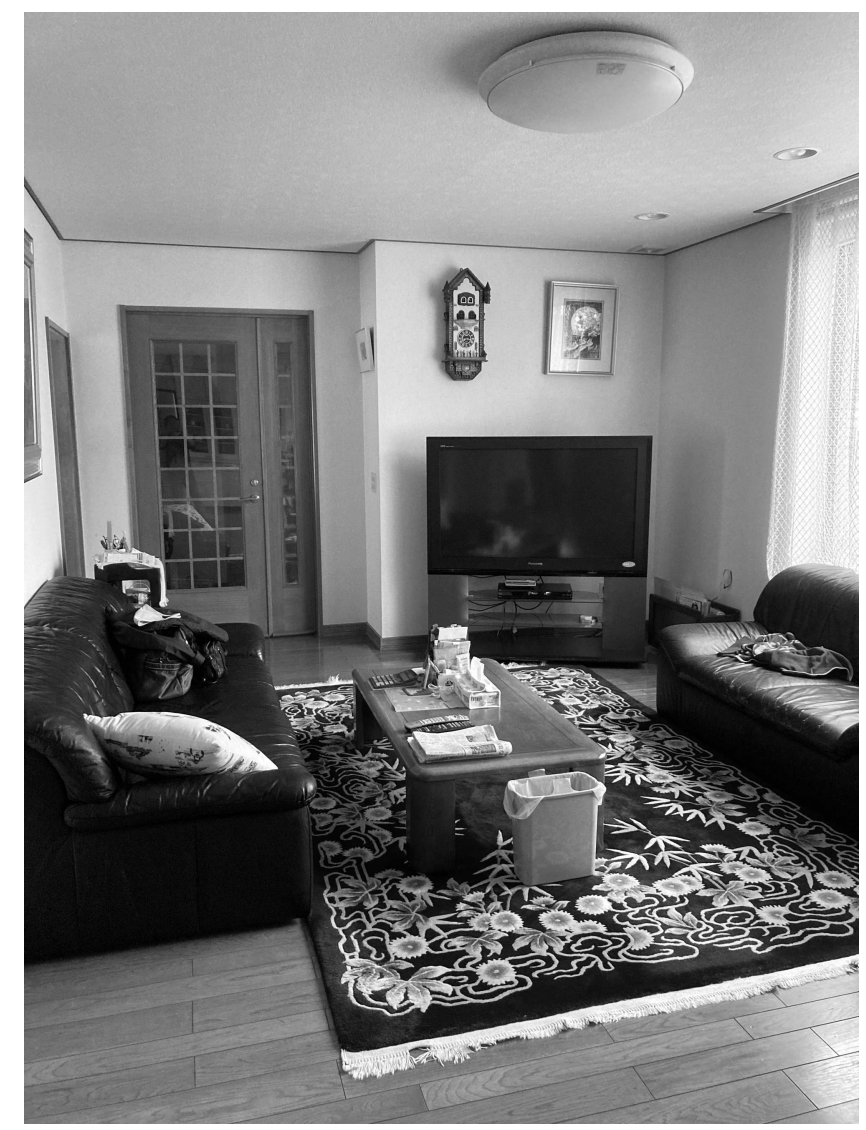

Figure 2.9 Japanese living room; photograph by Masako Ishii-Kuntz.

childrearing, domestic management and the creation of a patriotic, thrifty household.

In the succeeding eras, the gendered division of household labour came to be firmly accepted in Japanese families. This sharp division of women and men's roles at home continued during the post-war economic boom from the 1950s to the 1970s. During this period, Japanese salaried men were frequently called 'corporate warriors' who dedicated their lives to their companies. Many women, in contrast, became 'professional housewives' and kept themselves busy taking care of their husbands and children at home.

Since the 1980s and especially after the collapse of the bubble economy in the early 1990s, several incidents and demographic shifts necessitated three major changes in women and men's roles in Japanese homes. First, several shocking cases of child abuse and child killing by mothers were reported in 
the Japanese media in the 1980s, which consequently led to the collapse of the 'maternal instinct myth.' In addition, Makino (1982) found that mothers' isolated home environments and lack of husbands' childcare involvement increased levels of maternal stress and anxiety. These findings also contributed to the re-evaluation of home and family roles for many Japanese couples.

Second, Japan's birth rate began to decline in the late 1970s. The decline in fertility continues today, raising the government's concerns over the shortage of labour force in the near future. One 'solution' that the government has been promoting is to increase men's involvement at home assuming that paternal involvement would encourage their wives to have more babies. Several governmental campaigns to increase fathers' participation in childcare since 1999, for example, have contributed to raise awareness among Japanese people of the importance of paternal involvement (Ishii-Kuntz, 2013).

Third, there has been an increase in labour force participation among Japanese women, including those of childbearing age. According to the Labour Force Survey (Ministry of Internal Affairs and Communications. Statistics Japan, 2016), 57.1\% of women aged 25 to 44 were employed in 1986 , but this figure increased to $72.7 \%$ by 2016 . With this increase, many married women and men have found it necessary to reassign their roles at home.

\section{The modern Japanese home as a gendered space}

Despite several attempts to bring about equality in women and men's roles at home, we still see that these roles are sharply divided by gender. As a result, women are more likely than men to experience work-life conflict.

Encouraged by the Government's Act on Promotion of Women's Participation and Advancement in the Workplace fully enforced in 2016, an increasing number of Japanese women have been entering the labour force in recent years. However, many women find it rather difficult to realise their work-family balance mainly due to the shortage of day care centres as well as to the lack of support of their bosses and co-workers.

Despite the increasing conflicts that Japanese women are experiencing between work and family demands, outsourcing of childcare and housework is still uncommon in Japanese homes, unlike in Norway. Nagai (2016) reports an increase since the mid-1990s in terms of the costs of outsourcing cooking. However, the outsourcing of cooking includes purchasing ready-made foods at the supermarket and eating out at restaurants, but does not include the real labour of cooking in the home. Additionally, the cost of outsourcing housework constitutes only $0.03 \%$ of total household expenditures, which implies that for many Japanese homes, this not a common phenomenon. This may also be explained by the hesitancy that many Japanese express towards allowing 'outsiders' to enter their homes. 
In summary, with an increase of women's labour force participation, the sharing of familial roles at home has become a necessity in Japan. In reality, however, as discussed in chapter 3, men still work longer hours than do women, thus many fathers find it difficult to be involved in childcare and housework. Women, on the other hand, are burdened by an overwhelming amount of family and work demands. Unless there are major structural and attitudinal changes, gender equality at home may not be realised in Japanese society in the foreseeable future.

\section{The social meaning of the home: Similarities and differences}

In this chapter we asked: What gendered meanings are ascribed to the home in Norway and Japan, both historically and today, and what kind of similarities and differences can we see? What are the most significant issues which emerge when gender is at stake?

From the analysis, we have learnt that both Japan and Norway show a trend toward single household occupancy, with almost one-third of the households being single occupied. Also, in both countries, separate spheres for productivity for women (home) and men (work outside) have been celebrated in popular discourse, codified in law, instrumental in devising education plans, and naturalised through decades of practice. In Norway there were housewife schools which taught women to become proper homemakers, whereas in Japan, the 'good wife, wise mother' ideology of the late 19th to early 20th centuries served to educate women and imbue them with a mission. Even as domesticity no longer describes many Japanese women's lives, we can still see their influence in women's strong feelings about motherhood and the home as a venue of creativity.

In both cases, we note that the home is still a gendered sphere where women continue to be most responsible for housework and for childcare, although more recently there have been shifts towards men taking more responsibility, in both contexts. At the same time, the Norwegian dual earner/dual carer system and the parental leave system have gone a long way towards normalising fathers taking on childcare and spending more time on housework. This is helped by the relatively short working day for both men and women, which means that in principle both parents are at home from late afternoon. This stands in contrast with the long working hours expected in Japan, especially for men, which precludes many men from undertaking as much household and childcare duties, and which puts a relatively greater burden on working mothers.

Despite the contrast between Norway and Japan in terms of working hours, in Norway, there is still a lot of discussion about the 'time bind.' When addressing this time bind, it is taken for granted that somehow a couple should at least in principle be gender-equal when dealing with time stresses. At the same time this 'gender equality' is sometime achieved by 


\section{Guro Korsnes Kristensen et al.}

outsourcing domestic work to non-Norwegian women cleaners, paradoxically reinforcing the traditional feminised domestic sphere of the housework era of Norway. In Japan, recent debates have similarly reinforced that achieving a work-family balance is high on the public agenda, as campaigns for day-care facilities have shown.

The main difference between Norway and Japan is that in Japan a very strict distinction is maintained between the public and private spheres. Whereas the Japanese home is very much a private space where it is rare for 'outsiders' to the family to be invited, the Norwegian home is more likely to be a space where visitors are welcomed. Having said that, open hospitality is not as common in today's Norway as in, for example, Southern European countries, and immigrants report that they find Norwegian people generally reserved, and that they are very rarely invited into Norwegian homes (Penner, forthcoming). However, while Norwegian families can mitigate this pressure by outsourcing hourswork to (most often migrant and female) domestic labourers, this is not a possibility in Japan, given the tightly guarded domestic sphere and the greater reluctance to allow outsiders into the home.

Either way, gender relations are changing in both countries and the world is getting more international. Japanese homes are also decorated with furniture from IKEA, and Norwegian home owners are talking about Japanese minimalism and zen when discussing their home décor. It remains to be seen how global trends interacting with local customs and needs will shape the home and its potentially gendered identity in the future.

\section{Note}

1 Eiendom Norge. Den norske boligmodellen. https:/eiendomnorge.no/om-oss/ visjon-og-verdier/den-norske-boligmodellen

\section{References}

Aarseth, H. (2011). Moderne familieliv. Den likestilte familiens motivasjonsformer [Modern family life. The gender equal family's forms of motivation]. Cappelen Damm.

Act on Promotion of Women's Participation and Advancement in the Workplace (2016). Gender Equality Bureau Cabinet Office. Retrieved June 20, 2021, from https://www.gender.go.jp/english_contents/pr_act/pub/pamphlet/women-and-men $17 / \mathrm{pdf} / 2-5 . \mathrm{pdf}$

Anderson, B. (2000). Doing the dirty work? The global politics of domestic labour. Zed Books.

Andersen, E. (2020). Flere bor alene [More live alone]. Statistisk Sentralbyrå. [Report]. https://www.ssb.no/befolkning/artikler-og-publikasjoner/flere-bor-alene

Avdem, A.J., \& Melby, K. (1985). Oppe forst og sist $i$ seng: Husarbeid $i$ Norge fra 1850 til $i$ dag [First one up and last to bed: Housework in Norway from 1850 to today]. Universitetsforlaget. 
Brusdal, R. (2006). The Norwegian home-way of life, way of consuming. World Leisure Journal, 48(1), 34-39.

Carsten, J. (2004). After kinship. Cambridge University Press.

Chatterjee, A. (forthcoming 2022). Home away from home? Belonging and dislocation among migrant domestic worker. In S. Jha, \& P.K. Singh (Eds.), Home, Belonging and Memory in Migration: Leaving and Living. Routledge.

Cieraad, I. (1999). At home: An anthropology of domestic space. Syracuse University Press.

Danielsen, H., Larsen, E., \& Owesen, I.W. (2014). Norsk likestillingshistorie 18142013 [The history of Norway's gender equality 1814-2013]. Fagbokforlaget.

Døving, R. (2020). Det bilaterale slektskapets spenninger i prosjekt kjernefamilie. [Revisiting kitchen-table society: Bilateral tensions in the nuclear family]. Norsk antropologisktidsskrift, 1-2(31), 20-34.

Døving, R. (2001). Vaffelhjertets makt - Norske kvinners hushold [The power of the waffle heart: Norwegian women's household]. In E.D. Holm, \& S. Meyer (Eds.), Varene tar makten - makt og demokratiutredningen 1998-2003 [The goods are in power - the power and democracy investigation] (pp. 151-190). Gyldendal Norsk Forlag.

Ellingsæter, A.L., \& Leira, A. (Eds.) (2006). Politicising parenthood: Gender relations in welfare states. Policy Press.

Erel, U. (2011). Reframing migrant mothers as citizens. Citizenship Studies, 15(6), 695-709.

Friberg, J.H., \& Tyldum, G. (2007). Polania i Oslo. En studie av arbeids- og levekar blant polakker $i$ hovedstadsomrade [Polania in Oslo: An exploration of the working and living conditions among Polish people in Oslo.]. Fafo.

Gender Equality Bureau Cabinet Office. (2016). Heisei 29nen shakai seikatsu kihon chousa no kekka kara (Findings from 2016 Basic Survey on Social Life.) Retrieved June 20, 2021, from http://wwwa.cao.go.jp/wlb/government/top/hyouka/k_42/ pdf/s1-2.pdf

Gullestad, M. (1992). The art of social relations. Essays on culture, social action and everyday life in modern Norwayt. Scandinavian University Press.

Gullestad, M. (1993). Home decoration as popular culture. Constructing homes, genders and classes in Norway. In de Valle, T. (Eds.). Gendered Anthropology. Routledge.

Gullestad, M. (2001). Kitchen-table society. Universitetsforlaget. (Original work published in 1984).

Gullestad, M. (2002). Det norske sett med nye øyne. Kritisk analyse av norsk innvandringsdebatt. (New perspectives on 'Norwegian ways of being'. A critical analysis of Norwegian immigration debates). Universitetsforlaget.

Hagemann, G., \& Roll-Hansen, H. (2005). Housewives: Meanings and implications of unpaid work. Issues in contemporary history. Oslo Academic Press.

Ishii-Kuntz, M. (1994). The Japanese father: Work demands and family roles. In J.C. Hood (Ed.), Men, work and family (pp. 45-67). Sage.

Ishii-Kuntz, M. (2013). Sociology of child caring men. Mierva.

Kettenhofen, L. (2021). Rate of owned dwellings in Japan from 1973 to 2018. Statistica. [Report]. https://www.statista.com/statistics/1005428/home-ownership-rate-japan/

Kitano, H.H.L. (1976). Japanese Americans: The evolution of subculture. Prentice-Hall. 


\section{Guro Korsnes Kristensen et al.}

Kitterød, R., \& Lappegård, T. (2012). A typology of work-family arrangements among dual-earner couples in Norway. Family Relations, 61(4), 671-685.

Klepp, I.G. (2006). Skittentøyets kulturhistorie: Hvorfor kvinner vasker kloer [The cultural history of the dirty laundry. Why women are doing the laundry]. Novus.

Kristensen, G.K. (2016). Paid migrant domestic labour in gender-equal Norway: A win-win arrangement. In B. Gullikstad, G.K. Kristensen, P. Ringrose (Eds.). Paid migrant domestic labour in a changing Europe. Questions of gender equality and citizenship (pp. 169-193). Palgrave Macmillan.

Kristensen, G.K. (2017).'My home is my castle.' The Norwegian home in times of paid migrant domestic labour.' Culture and Organization 23 (4), 1-14.

Lasch, C. (1977). Haven in a heartless world: The family besieged. Basic Books.

Lister, R. (2003). Citizenship: Feminist perspectives. Palgrave.

Lorentzen, J. (2013). The History of Fatherhood in Norway, 1850-2012. Palgrave.

Lorentzen, A.G. (2008). Hjem kjore hjem. En empirisk studie av drømmen om det norske hjem [Home sweet home. An empirical exploration of the imagined Norwegian home] [Master's Thesis, University of Oslo].

Makino, K. (1982). Mothers of young children and their childcare anxiety. Journal of Family Education Research Institute, 3, 34-51.

Mills, M., van de Bunt, G.G., \& de Bruijn, J. (2006). Comparative research. Persistent problems and promising solutions. International Sociology, 21(5), 619-631.

Ministry of Internal Affairs and Communications. Statistics Japan (2016). Roudouryoku chousa nenpo (Annual report of the Labour force survey). Retrieved June 20, 2021, from https:/www.stat.go.jp/data/roudou/report/2016/ index.html

Moore, B. (1984). Privacy: Studies in social and cultural history. Sharpe.

Muta, K. (1996). Postwar family: Citizen and nation building in modern Japan and women. Shinyosha.

Nagai, K. (2016). Trends of outsourcing housework in Japan: Expenditures from household finances survey. Kikan Kakei Keizai, 109, 75-89.

Pateman, C. (1989). The disorder of women: Democracy, feminism and political theory. Stanford University Press.

Penner, A. (forthcoming). "How do you meet people here?" Exploring cosmopolitan hospitality in rural Norway. In Simonsen, J.K., Bottos, L.C. \& Chen, S. (eds.) Cosmopolitan networks.

Sasahara, M. (2008). An analysis of infant period gender-socialization processes, based on a survey of Shizuoka Prefecture High School Students. Studies in Informatics, Shizuoka University, 14, 33-59.

Smith, K.C., \& Schooler, C. (1978). Women as mothers in Japan: The effects of social structure and culture on values and behavior. Journal of Marriage and Family, 40(3), 613-620.

Solheim, J. (1998). Den åpne kroppen. Om kjønnssymbolikk i moderne kultur [The open body: On gendered symbols in modern culture]. Pax Forlag A/S.

Solheim, J. (2007). Kjonn og modernitet. (Gender and modernity). Pax Forlag A/S. Sollund, R. (2010). Regarding au pairs in the Norwegian welfare state. European Journal of Women's Studies, 143(17), 143-160. 
Somerville, P. (1997). The social construction of home. Journal of Architectural and Planning Research, 14(3), 226-245.

Statistisk Sentralbyrå. (2018). Women and men in Norway. [Report]. https:/www.ssb.no/ en/befolkning/artikler-og-publikasjoner/_attachment/347081?_ts=1632b8bcba0

Tama, Y. (1985). Creation of maternal instinct myth-Analysis of modern Western medicine and psychological analysis. Joseigaku Nenpo, 6, 16-25.

Utlendingsdirektoratet. (2020). Utdanningstillatelser etter statsborgerskap og type tillatelse (2020) [Permissions granted for education by citizenship and category of permission]. [Report]. https://www.udi.no/statistikk-og-analyse/statistikk/ utdanningstillatelser-etter-statsborgerskap-og-type-tillatelse-2020/ 